\title{
MENEROPONG KONSEP PERTUMBUHAN EKONOMI (Telaah atas Kontribusi Sistem Ekonomi Islam atas Sistem Ekonomi Konvensional)
}

\author{
Zainal Abidin \\ (Jurusan Syari'ah STAIN Pamekasan, jln. Pahlawan KM. 04 Pamekasan, \\ email: zainal.madura@gmail.com)
}

\begin{abstract}
Abstrak
Manusia sebagai makhluk yang memiliki berbagai kebutuhan yang harus dipenuhi untuk mempertahankan kelangsungan hidupnya. Untuk mendapatkan kebutuhan-kebutuhan dasar tersebut, manusia harus berusaha untuk mendapatkannya melalui berbagai bidang termasuk di bidang ekonomi. Dalam pandangan ekonomi konvensional, pertumbuhan ekonomi secara garis besar ditujukan untuk kesejahteraan materi. Islam juga memandang bahwa pertumbuhan ekonomi merupakan satu sarana untuk menjamin tegaknya keadilan sosial secara kekal. Faktor-Faktor pertumbuhan ekonomi adalah sumbersumber investasi yang identik dengan modal, sumber daya manusi yang identik dengan tenaga kerja, enterpreneurship (jiwa wirausaha) dan kemajuan teknologi. Semua faktor tersebut juga dikenal dalam Islam dan tidak ada pertentangan bahkan dukungan dari konsep Islam terhadap faktor-faktor tersebut. Pengukuran pertumbuhan ekonomi dalam ekonomi Islam adalah sama dengan ekonomi konvensional, hanya saja ada tambahan unsur Zakat dalam proses perhitungannya GNP. Pertumbuhan ekonomi dalam perspektif Islam harus memasukkan aspek aksiologis (nilai, moral) agar pertumbuhan ekonomi tidak hanya diorientasikan kepada kesejahteraan materi saja melainkan memasukkan juga aspek ruhaniyah.
\end{abstract}

\footnotetext{
Abstract

Human encompass number of needs that must be fulfilled to survive. Exploring economic field has been one of varied ways to encounter the basic needs. From the perspective of conventional economy, the economic growth is directed to material welfare. Islam views economic growth as media to endorse social justice everlastingly. The factors of economic growth are source of investation referring to capital, human
} 
resource referring to labor, enterpreneurship, and technology progress. Islam also recognizes those factors and there is no support and conflicts against the factors. Islam and conventional economy have similar economic growth measurement except the insertion of zakat (obligation to contribute to those in need or to religious activities) element on the process of GNP counting. Islam recommends the aspects of moral and value to be considered in economic growth in order to include spiritual aspect as well as material welfare.

\author{
Kata-kata kunci \\ ekonomi Islam, ekonomi konvensional, enterprenuership
}

\title{
Pendahuluan
}

Manusia sebagai makhluk yang memiliki berbagai kebutuhan yang harus dipenuhi untuk mempertahankan kelangsungan hidupnya. Kebutuhan-kebutuhan tersebut meliputi kebutuhan primer, kebutuhan skunder dan kebutuhan-kebutuhan pelengkap lainnya.

Dua kebutuhan yang dibutuhkan oleh semua makhluk hidup khususnya manusia. Untuk mendapatkan kebutuhan-kebutuhan dasar tersebut, manusia harus berusaha untuk mendapatkannya melalui berbagai bidang termasuk di bidang ekonomi.

Secara historis, ilmu ekonomi muncul dari adanya kebutuhankebutuhan dasar yang disebutkan di atas, namun dalam kenyataannya tidak semua manusia mampu untuk memenuhi kebutuhan tersebut, maka yang perlu dipikirkan adalah bagaimana manusia berusaha agar bisa mengelola, mengatur dan mensiasati terpenuhinya kebutuhan-kebutuhan dasar tersebut.

Salah satu usaha yang dapat dilakukan manusia baik secara individual maupun secara kolektif adalah bagaimana meningkatkan pertumbuhan ekonomi dengan memanfaatkan faktor-faktor pertumbuhan ekonomi seperti sumber daya alam, kemajuan teknologi, dan lain sebagainya.

Maka dalam hal ini, meningkatnya pertumbuhan ekonomi merupakan salah satu syarat penting bagi terpenuhinya kebutuhan manusia. Tidak adanya pertumbuhan berarti mandegnya aktivitas kehidupan ekonomi yang itu akan berakibat kepada berkurangnya - 
untuk tidak mengatakan hilangnya- income yang merupakan kebutuhan dasar manusia. Pertumbuhan ekonomi bisa dilihat dari berbagai indikator. Indikator-indikator tersebut di antaranya adalah meningkatnya produksi (out put), terciptanya lapangan kerja baru, meningkatnya iklim investasi dan lain sebagainya.

Dalam pandangan ekonomi konvensional, pertumbuhan ekonomi secara garis besar ditujukan untuk kesejahteraan materi, yang itu hanya berdimensi jangka pendek, atau dengan ungkapan lain hanya untuk kesejahteraan duniawi tanpa diimbangi dengan tujuan ukhrawi. Pemasukan istilah yang mencerminkan kepuasan ruhaniyah dalam fungsi ini tidak akan menimbulkan masalahmasalah matematis, karena sifatnya yang tidak berwujud. Di sisi lain Islam juga memandang bahwa pertumbuhan ekonomi merupakan satu sarana untuk menjamin tegaknya keadilan sosial secara kekal. ${ }^{1}$

Berdasarkan beberapa pandangan di atas, makalah ini akan mencoba untuk memaparkan berbagai permasalahan tersebut yang diawali dengan pendahuluan, diikuti kemudian dengan pembahasan tentang definisi pertumbuhan ekonom, faktor-faktor pertumbuhan ekonomi, pengukuran pertumbuhan ekonomi, dan diakhiri dengan pendekatan aksiologis Islam dalam pertumbuhan ekonomi.

\section{Definisi Pertumbuhan Ekonomi}

Pertumbuhan ekonomi (economic growth) didefinisikan sebagai peningkatan dalam kapasitas suatu bangsa jangka panjang untuk memproduksi aneka barang dan jasa bagi rakyatnya. Kapasitas itu bertumpu pada kemajuan teknologi produksi. Secara konvensional, pertumbuhan diukur dengan kenaikan pendapatan nasional (PNP, GNP) perkapita. ${ }^{2}$

Pembangunan ekonomi (economic development) adalah suatu konsep yang lebih luas. Konsep ini mencakup juga modernisasi lembaga, baik yang bersifat ekonomi, seperti pemerintah, kota, desa, cara berpikir, tidak saja yang berkenaan dengan tujuan agar dapat memproduksi secara efisien, melainkan juga agar mengkonsumsi

\footnotetext{
1 Syed Nawab Haidar Naqvi, Etika dan Ilmu Ekonomi Suatu Sintesis Islami, terj. Husin Anis (Bandung: Mizan, 1991), hlm. 134

2 Gerardo P. Sicat, H. W. Arndt, Ilmu Ekonomi Untuk Konteks Indonesia, ter. Nirwono, (Jakarta: LP3ES, 1991), hlm. 345
} 
secara rasional dan hidup lebih baik. ${ }^{3}$ Kesemuanya itu membuka jalan bagi pertumbuhan ekonomi dan mendahului atau berbarengan dengan perubahan sosial.

Sementara itu, dalam Islam pertumbuhan ekonomi didefinisikan sebagai:

A sustained growth of a right kind of output which can contribute to human welfare. ${ }^{4}$ (Sebuah pertumbuhan produksi atau hasil yang terus menerus dengan cara yang benar yang dapat memberikan konstribusi bagi kesejahteraan umat manusia).

Dari kedua definisi pertumbuhan di atas, kita dapat melihat perbedaan mendasar antara pandangan ilmu ekonomi konvensional dengan ilmu ekonomi Islam. Perbedaan mendasar tersebut terletak pada tujuan akhir dari pertumbuhan ekonomi itu sendiri. Ilmu ekonomi konvensional hanya berorientasi kepada pertumbuhan yang tinggi dari suatu aktifitas kehidupan ekonomi, tanpa menyertainya dengan distribusi yang merata dari output yang dihasilkan, yang ujung-ujungnya berakhir pada kesejahteraan materi yang pendistribusiannya tidak merata untuk kesejahteraan manusia. Berbeda dengan pandangan ilmu ekonomi konvensional, ilmu ekonomi Islam memandang pertumbuhan ekonomi sebagai sebuah sarana untuk meningkatkan kesejahteraan materi manusia tanpa memandang ras, agama, dan bangsa. Lebih dari itu, ilmu ekonomi Islam mempunyai orientasi ganda dalam hal ekonomi yaitu kesejahteraan materi (duniawi) dan kepuasan batin (ukhrawi).

Adapun yang berkaitan dengan pembangunan ekonomi (economic development) tidak ada perbedaan antara ilmu ekonomi konvensional, keduanya memandang bahwa pertumbuhan ekonomi merupakan komponen dari pembangunan ekonomi. Cakupan dari pembangunan ekonomi lebih luas dari cakupan pertumbuhan ekonomi.

\section{Faktor-Faktor Pertumbuhan Ekonomi}

Dalam pembahasan tentang faktor-faktor pertumbuhan ekonomi ini perlu kita ketahui bahwa keberadaan faktor-faktor

\footnotetext{
3 Ibid. Lihat juga Sumitro Djojohadikusumo, Perkembangan Pemikiran Ekonomi, Dasar Teori Ekonomi Pertumbuhan dan Ekonomi Pembangunan (Jakarta: LP3ES, 1994), hlm. 1.

${ }^{4}$ A. H. M. Sadeq, Islamic Economic, (Lahore: Islamic Publication (Pvt) Limited, 1989), hlm. 24
} 
pertumbuhan ekonomi ini memberikan kontribusi besar bagi pertumbuhan ekonomi. Adapun faktor-faktor pertumbuhan ekonomi tersebut adalah sebagai berikut:

\section{Sumber-sumber Investasi}

Pertumbuhan mensyaratkan adanya sumber-sumber investasi untuk meningkatkan produksi dari aset-aset fisik yang menghasilkan aliran pendapatan ke depan. Aset-aset fisik tersebut meliputi pabrikpabrik dan mesin-mesin industri yang membantu terjadinya pertumbuhan produksi.

Ketentuan formasi modal dalam pertumbuhan ekonomi dijelaskan secara mendalam dalam berbagai sumber ilmu ekonomi. Beberapa penulis dalam bidang ekonomi yang menunjukkan perhatian kepada perkembangan sumber daya manusia tidak menyanggah pentingnya modal dalam membantu tingkat pertumbuhan ekonomi.

Proses pertumbuhan ekonomi meliputi mobilisasi sumbersumber yang memadai bagi investasi, konversinya ke dalam aset-aset fisik yang produktif, dan faktor-faktor lain. Ada dua sumber modal yaitu sumber domestik dan sumber dari luar. Berkaitan dengan sumber-sumber modal dari luar, Islam melihat bahwa merupakan hal yang penting untuk mengadakan kerjasama dengan negara-negara Islam dari luar dan menghindarkan diri dari ribâ dalam pengelolaan keuangan dan membebaskan diri dari pengaruh perbudakan sosial budaya dan politik ekonomi Barat.

Beberapa potensi penting dari ekonomi Islam adalah bagaimana memobilisasikan sumber-sumber domestik untuk pertumbuhan ekonomi. Ada tiga aspek yang bisa dikemukakan di sini berkaitan dengan sumber-sumber domestik tersebut yaitu: ${ }^{5}(1)$ potensi menabung; (2) mobilisasi untuk menabung; (3) alokasi dan pemanfaatan tabungan untuk pertumbuhan ekonomi

\section{Sumber Daya Manusia}

Sumber daya manusia merupakan faktor penting dalam pertumbuhan ekonomi. ${ }^{6}$ Manusia merupakan pelaku-pelaku yang aktif dalam pertumbuhan ekonomi yang melakukan eksploitasi

\footnotetext{
5 Abdul Hasan Muhammad Sadeq, Economic Development In Islam (Malaysia: Pelindung Publicarion, 1990), hlm. 16

${ }^{6}$ M. Abdul Mannan, Teori dan Praktek Ekonomi Islam, terj. M. Nastangin (Yogyakarta: Dana Bakti Prima Yasa, 1997), hlm. 380
} 
terhadap sumber daya alam, pengumpulan modal, pembangunan sosial, ekonomi dan institusi-institusi politik yang menggiatkan proses pertumbuhan. Mereka menyediakan dua faktor penting dalam proses pertumbuhan yaitu sebagai pekerja dan pelaku enterprenuership.

Kepiawaian yang efisien seorang pekerja sangat penting dalam pertumbuhan ekonomi. Efisien dalam bekerja mensyaratkan dua kualitas yatiu profesionalisme dan kualitas moral adalah kualitas moral. Profesionalisme bekerja meliputi keterampilan dan efisien dalam bekerja. Sedangkan kualitas moral adalah kualitas yang memberikan dorongan untuk bekerja secara efisien, ikhlas, dan jujur. ${ }^{7}$

Kedua kualitas di atas, yaitu profesionalisme dan moral adalah sangat penting untuk mendapatkan kontribusi maksimal dalam pertumbuhan ekonomi pekerja yang profesional dengan keterampilan yang tinggi tanpa kejujuran, keikhlasan tidak dapat memberikan kontribusi apa-apa bagi proses pertumbuhan, begitu juga sebaliknya dengan pekerja yang mempunyai kejujuran, keikhlasan tapi tidak memiliki keterampilan juga tidak bisa memberikan kontribusi apa-apa bagi pertumbuhan ekonomi. Maka dengan demikian, keduanya merupakan dua sisi mata uang yang tidak bisa dipisahkan satu sama lain.

\section{Enterprenuership (Jiwa Wiraswasta)}

Ditegaskan oleh beberapa ekonom bahwa enteprenuership merupakan salah satu faktor yang sangat penting dalam pertumbuhan ekonomi. Menurut pendapat Schumpeter, pertumbuhan ekonomi ditentukan oleh fungsi yang dinamis dari enterprenuership, dan fungsi dari enterprenuership ini adalah suatu inovasi. ${ }^{8}$ Walaupun - menurut beberapa pendapat ekonomi yang lain - fungsi yang inovatif enterprenuership tersebut tidak begitu nampak dalam perusahaan-perusahaan negara dan dalam penafsiran yang lebih luas. Kontribusi mendasar dari enterprenuership dalam menggerakkan roda pertumbuhan ekonomi tidak bisa disanggah, karena perannya yang begitu vital.

Islam mendukung bertumbuh-kembangnya jiwa enterprenuership dalam usaha untuk meningkatkan pertumbuhan

7 Ibid, 23

8Sadeq, Islamic, hlm. 34 
ekonomi. Islam memberikan motivasi positif kepada berbagai aktifitas kehidupan ekonomi dengan maksud untuk mendapatkan sumber penghidupan yang halal. Dari pokok pikiran sumber-sumber enterprenuership ataupun non-enterprenuership dalam mendapatkan harta, ada dua pengertian yang agak luas dari apa yang dimaksud dengan mencari pendapatan: Pertama, bekerja untuk orang lain atas dasar gaji dan upah dalam jumlah tertentu. Kedua, melakukan usahausaha wiraswasta. Islam menganjurkan umatnya untuk bekerja untuk mendapatkan upah atau gaji, baik yang dilakukan kepada orang lain maupun yang dilakukan secara mandiri (wiraswasta). Dalam alQur'an Allah memerintahkan untuk menggali dan mendapatkan karunia yang banyak yang disediakan oleh Allah, hal itu bisa dilakukan melalui wiraswasta.

Dalam aktivitas ekonomi ada dua motif yang dianjurkan dalam aktifitas kewiraswastaan, yatu: motivasi keuntungan dan motivasi untuk berprestasi. Namun demikian, segala aktivitas bisnis harus selalu mengacu kepada ketentuan-ketentuan yang telah ditentukan oleh syari'ah yaitu aktifitas bisnis yang halal.

\section{Kemajuan Teknologi}

Tidak dapat dipungkiri bahwa kemajuan teknologi memberikan kontribusi yang cukup tinggi bagi pertumbuhan ekonomi. Kemajuan dalam teknologi menyebabkan bertambahnya produk yang dihasilkan oleh setiap satuan faktor satuan produksi atau input yang digunakan. ${ }^{9}$ Tatkala tenaga kerja menjadi relatif langka, kemajuan teknologi menjurus ke arah penemuan proses yang "hemat tenaga kerja". Namun penemuan juga menghemat faktor lain. Sebagai contoh, penyulapan lahan-lahan dari laut atau rawa, dan juga penterasan lahan, dapat dianggap sebagai penemuan yang menciptakan "penghemat lahan begitu pula halnya dengan praktek di bidang pertanian seperti penanaman kali dengan irigasi dan tumpang sari berbagai jenis tanaman yang berumur pendek.

Penemuan teknologi yang menghemat kerja mungkin akan membuat orang kehilangan pekerjaan untuk sementara waktu. Namun, perekonomian yang mengalami pertumbuhan cepat menciptakan bidang usaha baru juga berkat penemuan-penemuan yang mengakibatkan semakin sedikitnya kebutuhan akan tenaga

${ }_{9}$ Arnd, Ilmu Ekonomi, hlm. 348 
kerja dalam proses produksi yang menggantikan proses produksi yang lama itu.

Singkatnya, kemajuan teknologi merupakan faktor penting dalam pertumbuhan ekonomi, dan kiranya bermanfaat bila kita mengamati dampak keseluruhannya terhadap proses produksi.

Program teknologi meliputi dua bentuk inovasi, yaitu inovasi produk dan proses inovasi. ${ }^{10}$ Inovasi produk mengacu kepada pengenalan terhadap produk-produk baru yang tidak ada sebelumnya, atau pengenalan produk yang lebih unggul dibanding dengan produk sebelumnya. Adapun proses inovasi adalah untuk menemukan teknik-teknik baru dalam memproduksi produk-produk yang ada dengan ongkos yang lebih murah.

Islam tidak menentang konsep kemajuan teknologi sebagai sebuah kenyataan yang harus diterima dan dimanfaatkan, karena hal ini memberikan kontribusi yang cukup signifikan dalam proses teknologi. Ayat al-Qur'an membimbing manusia untuk menemukan dan mendapatkan hal-hal yang baru yang memberikan manfaat bagi banyak orang. Penemuan-penemuan baru tersebut bisa digunakan untuk mengeksplorasi sumber daya alam yang memang telah disediakan Allah bagi manusia untuk kesejahteraannya.

\section{Pengukuran Pertumbuhan Ekonomi}

Sebagaimana yang telah disinggung pada pembahasan di atas, pertumbuhan ekonomi dapat diukur melalui Gross National Product (GNP). GNP didefinisikan sebagai jumlah nilai akhir dari semua barang dan jasa yang dihasilkan dalam seluruh kegiatan ekonomi selama satu tahun. GNP ini mengukur aliran penghasilan negara (dari pertumbuhan ekonomi) selamak kurun waktu tertentu.

$\mathrm{GNP}=\mathrm{C}+\mathrm{I}+\mathrm{G}(\mathrm{E}-\mathrm{M})+\mathrm{Z}^{11}$

Di mana:

$\mathrm{C}=$ Consumer Spending

\footnotetext{
10 Abdul Hasan Muhammad Sadeq, Economic Development, 28

11 Tambahan huruf Z (Zakat) merupakan konsep ekonomi Islam dalam mengukur pertumbuhan ekonomi, dimana hal tersebut tidak terdapat dalam konsep ekonomi konvensional, dan tidak dimasukkan dalam pengukuran ini, karena yang diambil adalah dari pengukuran pertumbuhan ekonomi yang ada di Amerika Serikat pada tahun 1987, tapi bisa dimasukkan dalam negara yang memakai sistem ekonomi Islam dalam pelaksanaan ekonominya.
} 
$\mathrm{I}=$ Investement Spending

$\mathrm{G}=$ Output for Government

$(\mathrm{E}-\mathrm{M})=$ Net Export or Import

$\mathrm{Z}=$ Zakat

Contoh dari pengukuran (penghitungan) GNP adalah sebagai berikut:

The Major Component of GNP, 1897 (In Billion of \$)

\begin{tabular}{ll}
\hline Consumer Output (Expenditures) & $\$ 2,966$ \\
Investement Output (Expenditures) & $\$ 716$ \\
$\begin{array}{l}\text { Output For Government (Expenditures) } \\
\text { Output For Foreigners, Les Import }\end{array}$ & $\$ 924$ \\
From Abroad (Expenditures) & $\$ 120$ \\
\hline TOTAL OR GROSS NATIONAL PRODUCT & $\$ 4,486$
\end{tabular}

\section{Pendekatan Aksiologis Islam dalam Pertumbuhan Ekonomi}

Keseimbangan orientasi duniawiyah dan ukhrawiyah merupakan orientasi yang diidam-idamkan, khususnya dalam Islam. Berangkat dari orientasi yang seimbang antara duniawiyah (materi) dan ukhrawiyah (kepuasan non-materi) itulah Islam memandang bahwa pertumbuhan ekonomi merupakan satu sarana untuk menjamin tegaknya keadilan sosial secara kekal. Karena, menurut Islam, keadilan sosial adalah salah satu unsur penting dari dinamika sosial. Dalam konteks suatu perekonomian yang sedang tumbuh inilah kue pendapatan nasional dapat diperbesar demi kemungkinan masing-masing menerima secara adil dari pertumbuhan tersebut. Suatu lingkungan sosial yang di dalamnya setiap orang menikmati hasil pertumbuhan jelas lebih unggul dibandingkan dengan lingkungan sosial lainnya yang berisi orang-orang yang sebagian menikmati sementara yang lain menjadi korban. ${ }^{12}$

Dengan demikian, kebijaksanaan pertumbuhan dalam suatu perekonomian Islam harus ditujukan untuk menyeimbangkan distribusi pendapatan dari suatu pertumbuhan ekonomi untuk semua manusia tenpa memandang secara diskriminatif antara saru kelompok dengan kelompok yang lainnya.

Pertumbuhan ekonomi dalam perspektif Islam harus memasukkan aspek aksiologis (nilai, moral) agar pertumbuhan

12 Naqvi, Etika dan Ilmu, hlm. 134 
ekonomi tidak hanya diorientasikan kepada kesejahteraan materi saja melainkan memasukkan juga aspek ruhaniyah. Memasukkan aspek ruhaniyah ini dalam pandangan Islam tidak akan menimbulkan masalah-masalah matematis, karena sifatnya yang abstrak sebab, yang dioptimalisasikan, sekalipun ditinjau dari sudut pandang ilmu ekonomi neo-klasik, bukanlah arus konsumsi akan tetapi "nilai guna" yang berkaitan dengannya, yang ia sendiri adalah kualitas yang tidak berwujud.

Selanjutnya, maksimalisasi tingkat pertumbuhan pendapatan nasional per se, tanpa mempedulikan dampaknya atas distribusi pendapatan dan kesejahteraan umum, tidak dapat menjadi sasaran utama dalam perekonomian Islam. Dalam ekonomi Islam pertumbuhan ekonomi yang dituju adalah pertumbuhan optimal, baik dari segi kesejahteraan materi maupun rohani, Islam tidak memperkenankan konsumsi modal dan pertumbuhan yang melampaui batas yang memaksakan pengorbanan yang tidak alamiah bagi manusia. Jadi menurut Islam tingkat pertumbuhan yang rendah yang diiringi dengan distribusi pendapatan yang merata akan lebih baik daripada tingkat pertumbuhan yang tinggi tapi tidak dibarengi dengan distribusi yang merata. Namun demikian, yang lebih baik dari keduanya adalah pertumbuhan yang tinggi tanpa memaksakan pengorbanan yang tidak alamiah dari manusia dan disertai dengan distribusi pendapatan yang merata.

Penjelasan-penjelasan di atas selaras dengan apa yang dijelaskan oleh Abdurrahman Basalamah yang menyatakan bahwa ekonomi Islam merupakan tatanan yang bergerak berdasarkan dinamika dan motivasi al-Qur'an dan Hadits Rasulullah. Untuk itu, karena secara totalitas gerak dan interaksi hendaknya terkonsentrasikan pada kesadaran ibadah kepada Allah.13 Sebagaimana dijelaskan dalam al-Qur'an:

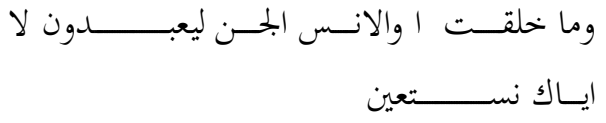

13 Abdurrahman Basalamah, Tatanan Ekonomi Islam Menurut Al-Qur'an dalam Penyelesaian Krisis Ekonomi Indonesia Dalam Islam dan Perdamaian Global (Yogyakarta: Madyan Press, 2002), hlm. 145 
Kedua ayat diatas memotivasi orang mu'min agar secara keseluruhan aktivitasnya, termasuk ekonomi, bernilai ibadah, yang beranjak dari kesadaran ibadah dan mengharapkan pertolongan allah, sehingga orang mu'min tumbuh rasa percaya diri dan tidak mempertahankan materi. untuk menguatkan alasan bahwa aktivitas ekonomi yang berdasarkan al-Qur'an dan al-hadits tersebut di atas sesuai dengan nilai-nilai kemanusiaan, kita bisa melihat kepada salah satu prinsip dasar ekonomi Islam yaitu hak untuk kepemilikan dan distribusi pendapatan yang merata yang didapatkan dari sumbersumber daya alam yang diberikan oleh allah kepada seluruh umat manusia tanpa memandang secara diskriminatif dan parsial. ${ }^{14}$

\section{Penutup}

Dari penjelasan-penjelasan $\mathrm{di}$ atas, penulis dapat mengemukakan beberapa kesimpulan berikut: Pertama, pertumbuhan ekonomi (economic growth) didefinisikan sebagai peningkatan dalam kapasitas suatu bangsa jangka panjang untuk memproduksi aneka barang dan jasa bagi rakyatnya. Sementara pertumbuhan ekonomi menurut Islam adalah sebuah pertumbuhan produksi atau hasil yang terus menerus dengan cara yang benar dan dapat memberikan kontribusi bagi kesejahteraan umat manusia.

Kedua, faktor-faktor pertumbuhan ekonomi adalah sebagai berikut: sumber daya alam, enterprenuership (kewirausahaan), sumber daya manusia dan yang terakhir adalah perkembangan teknologi.

Ketiga, untuk mengukur suatu pertumbuhan ekonomi secara nasional adalah memakai Gross National Product atau GNP dengan rumus: $\mathbf{G N P}=\mathbf{C}+\mathbf{I}+\mathbf{G}+(\mathbf{E}-\mathbf{M})$. Sementara dalam konsep ekonomi Islam ditambahkan huruf $\mathbf{Z}$ (zakat).

Keempat, pendekatan aksiologis Islam dalam pertumbuhan ekonomi adalah pendekatan yang menjadikan nilai (syarî'ah) atau moral sebagai dasar dari berbagai aktivitas kehidupan ekonomi. Disamping itu Islam juga menekankan kepada distribusi pendapatan yang merata bagi semua orang/kelompok tanpa memandang secara diskriminatif sebagai realisasi dari Islam sebagai rahmah li al-Âlamîn,

\footnotetext{
14 Muhammad Baqer Sadr dan Ayatullah Sayyid Mahmud Taleghani, Islamic Economics: Contemporary Ulama Perspectives (Kuala Lumpur: Iqra', 1991), hlm. 50.
} 
dengan orientasi bukan saja kesejahteraan materi tapi juga kesejahteraan ruhaniyah dalam suatu pertumbuhan ekonomi.

\section{Daftar Pustaka:}

Basalamah, Abdurrahman. Tatanan Ekonomi Islam menurut Al-Qur'an Dalam Penyelesaian Krisis Ekonomi Indonesia Dalam Islam dan Perdamaian Global. Yogyakarta: Madyan Press, 2002.

Djojohadikusumo, Sumitro. Perkembangan Pemikiran Ekonomi, Dasar Teori Ekonomi Pertumbuhan dan Ekonomi Pembangunan. Jakarta: LP3ES, 1994.

Mannan, M. Abdul. Teori dan Praktek Ekonomi Islam. Ter. M. Nastangin. Yogyakarta: Dana Bakti Prima Yasa, 1997.

Naqvi, Syed Nawab Haidar. Etika dan Ilmu Ekonomi Suatu Sintesis Islami, terj. Husin Anis. Bandung: Mizan, 1991.

Sadeq, Syed Nawab Haidar. Islamic Economic. Lahore: Islamic Publication (Pvt) Limited, 1989.

Sadeq, Abdul Hasan Muhammad. Economic Development in Islam. Malaysia: Pelindung Publicarion, 1990.

Sadr, Muhammad Baqer. dan Taleghani,Ayatullah Sayyid Mahmud. Islamic Economics: Contemporary Ulama Perspectives. Kuala Lumpur, Iqra', 1991

Sicat, Gerardo P. dan Arndt, H. W. Ilmu Ekonomi untuk Konteks Indonesia. terj. Nirwono. Jakarta: LP3ES, 1991. 